\title{
THRESHOLDS DEFINITION IN MOD13Q1 AND VGT-S10 TIME SERIES FOR COFFEE CROP AREA ESTIMATION IN TRIÂNGULO MINEIRO/ALTO PARANAÍBA
}

\author{
Michel Eustáquio Dantas Chaves \\ Federal University of Lavras (UFLA), Engineering Department, Campus, P. O. Box 3037, CEP 37.200-000, Lavras-MG, \\ Brazil \\ Corresponding author: micheldchaves@gmail.com
}

\section{Elizabeth Ferreira}

Federal University of Lavras (UFLA), Engineering Department, Campus, P. O. Box 3037, CEP 37.200-000, Lavras-MG, Brazil

\section{Antonio Augusto Aguilar Dantas \\ Federal University of Lavras (UFLA), Engineering Department, Campus, P. O. Box 3037, CEP 37.200-000, Lavras-MG, Brazil}

\begin{abstract}
In the last decades, remote sensing application in agricultural research has intensified to evaluate phenological cycles. Vegetation indices time series have been used to obtain information about the seasonal development of agricultural vegetation on a large scale. The objective of this study was to test the application of vegetation indices of the MODIS and SPOT-VEGETATION sensors to estimate the areas destined for coffee crops in the Triângulo Mineiro/Alto Paranaíba mesoregion. The results show that the vegetation indices NDVI and EVI of the product MOD13Q1 were more adequate for the estimation of land use over the time domain, especially NDVI. The best minimum threshold varies between $0.39-0.42$ and the best maximum threshold varies between $0.71-0.74$. The contribution of this work is that these thresholds can serve as subsidies for land use classification studies on a regional scale and for estimating areas for planting.
\end{abstract}

Index terms: Remote sensing, multisensor, vegetation indices, landscape, agriculture.

Received: October, 30, 2018 - Accepted: January, 10, 2019

\section{INTRODUCTION}

In order to reduce uncertainties and improve planning policies, the scientific community develops techniques for detect agricultural dynamics and gradual changes in the phenological stages. The result is the elaboration of tools related to the crop identification and monitoring, using remote sensing techniques and vegetation indices temporal analysis. Throughout the phenological cycle, each agricultural crop presents a peculiar development, reflected in different spectral and temporal patterns. Therefore, to understand the phenological dynamics, it is useful to evaluate the agricultural land use in a spectro-temporal approach.

Different studies have endorsed the use of vegetation indices time series as an option to discriminate agricultural crops and to generate area estimates, based on the variations of the cycle as a function of the phenological changes (Sakamoto et al., 2010; Arvor et al., 2011). In this context, the MODerate resolution Imaging Spectroradiometer (MODIS) and Sattelite Pour l'Observation de la Tèrre (SPOT-VEGETATION) sensors have been shown functionality to have an almost daily frequency of terrestrial imaging and high geometric quality images, as well as procedures for atmospheric correction of the images.

The MODIS sensor, with $250 \times 250$ meters of spatial resolution, presents the vegetation product MOD13Q1, which result from observations made every 16 days and the selection of the better quality pixels, composed by: (1) the Normalized Difference Vegetation Index (NDVI) and Enhanced Vegetation Index (EVI), (2) two images attesting the product quality and gather information about the pixels 
radiometry, NDVI and EVI Quality images, (3) the reflectance of the red, blue, near infrared and medium infrared bands, (4) an image referring to the angle of view, another one, referring to the solar zenith angle and a last one referring to the azimuth (Huete et al., 2002).

The MOD13Q1 is widely used for the identification and estimation of areas of agricultural crops in Brazil (Galford et al., 2008; Brown et al., 2013; Chaves et al., 2018).

The SPOT-VEGETATION with $1 \times 1 \mathrm{~km}$ spatial resolution features VGT-S10, a 10day image synthesis that uses the Maximum Value Composite (MVC) algorithm to select better quality pixels and generate images with least interference of NDVI and Normalized Difference Water Index (NDWI) (Maisongrande et al., 2004). The VGT-S10 images have a spatial resolution of $1 \mathrm{~km}$, temporal of 10 days and radiometric of 8 bits. The products are made available by the GEONETCast system, operated by GEONETCast Networking Centers.

The use of VGT-S10 time series already was used in analyzes on agriculture in Brazil (Chaves et al., 2011; Dubreuil et al., 2011; Araújo et al., 2012; Vicente et al., 2012), due to its extremely effective temporal frequency for the vegetative vigor monitoring.

The aforementioned composite products have relevance in the agricultural studies, but largely in homogeneous areas of cultivation, with extensive areas of the same crop, such as soybean in Mato Grosso and sugarcane in São Paulo, which provides pure pixel analysis, favoring the crop area estimation. The challenge is its application in heterogeneous areas of cultivation, such as the Triângulo Mineiro/Alto Paranaíba mesoregion, since the spatial variation of the crops is more diverse, the crop fields invariably are smaller than the sensors spatial resolution and the fields divide the geographical continuum with a diverse land uses.

Despite the quality of these products, there are few studies evaluating the influence of different spatial and temporal resolutions on the detection of phenological cycles. Also, it is necessary to verify the applicability of both in regions with heterogeneous land use and cover, in which small properties predominate, in order to eliminate subjectivities and speculations.
The objective of this work was to apply a methodology based on the analysis of vegetation indices temporal profiles from the MOD13Q1 and VGT-S10 products to identify thresholds for the coffee (Coffea arabica) crop areas estimation in a geographically heterogeneous mesoregion of land use and occupation, the Triângulo Mineiro/ Alto Paranaíba, Minas Gerais, identifying the best product and vegetation index for this purpose.

\section{MATERIAL AND METHODS}

\section{Study area}

The Triângulo Mineiro/Alto Paranaíba, Minas Gerais, Brazil (Figure 1) has 7 microregions and 66 municipalities, being situated between the geographic coordinates: $17^{\circ} 55^{\prime} 12^{\prime \prime}$ and $20^{\circ} 41^{\prime} 30^{\prime \prime}$ South latitude and $45^{\circ} 33^{\prime} 30^{\prime \prime}$ and $51^{\circ} 02^{\prime} 18^{\prime \prime}$ West longitude of Greenwich (IBGE, 2016a).

The Cerrado is the predominant biome in Triângulo Mineiro/Alto Paranaíba, having as characteristic vegetation the savanna, extract of grasses with interruptions by trees and shrublands (Scolforo et al., 2007). B1, B2, and B3 climates occur to the center and southeast and C2 (sub-humid) to the northeast, and precipitations vary between 1,300 and 1,700 mm annually, and the annual average temperature is $20^{\circ} \mathrm{C}$ (Scolforo et al., 2007).

\section{Official coffee planted area and precipita- tion data}

Data from 2009 to 2012 coffee planted area in the Triângulo Mineiro/Alto Paranaíba (Table 1) were obtained from the Systematic Survey of Agricultural Production (LSPA, in Portuguese), available in the IBGE Recovery System Automatic - SIDRA, in Portuguese (IBGE, 2016b).

Regarding the precipitation data used, as conventional meteorological stations provide records valid only for their surroundings, there is a low density of these meteorological stations. Thus, the use of estimated satellite data has been presented as a useful tool for obtaining data where there is no station and for large areas. In this context, the rainfall estimation using the 


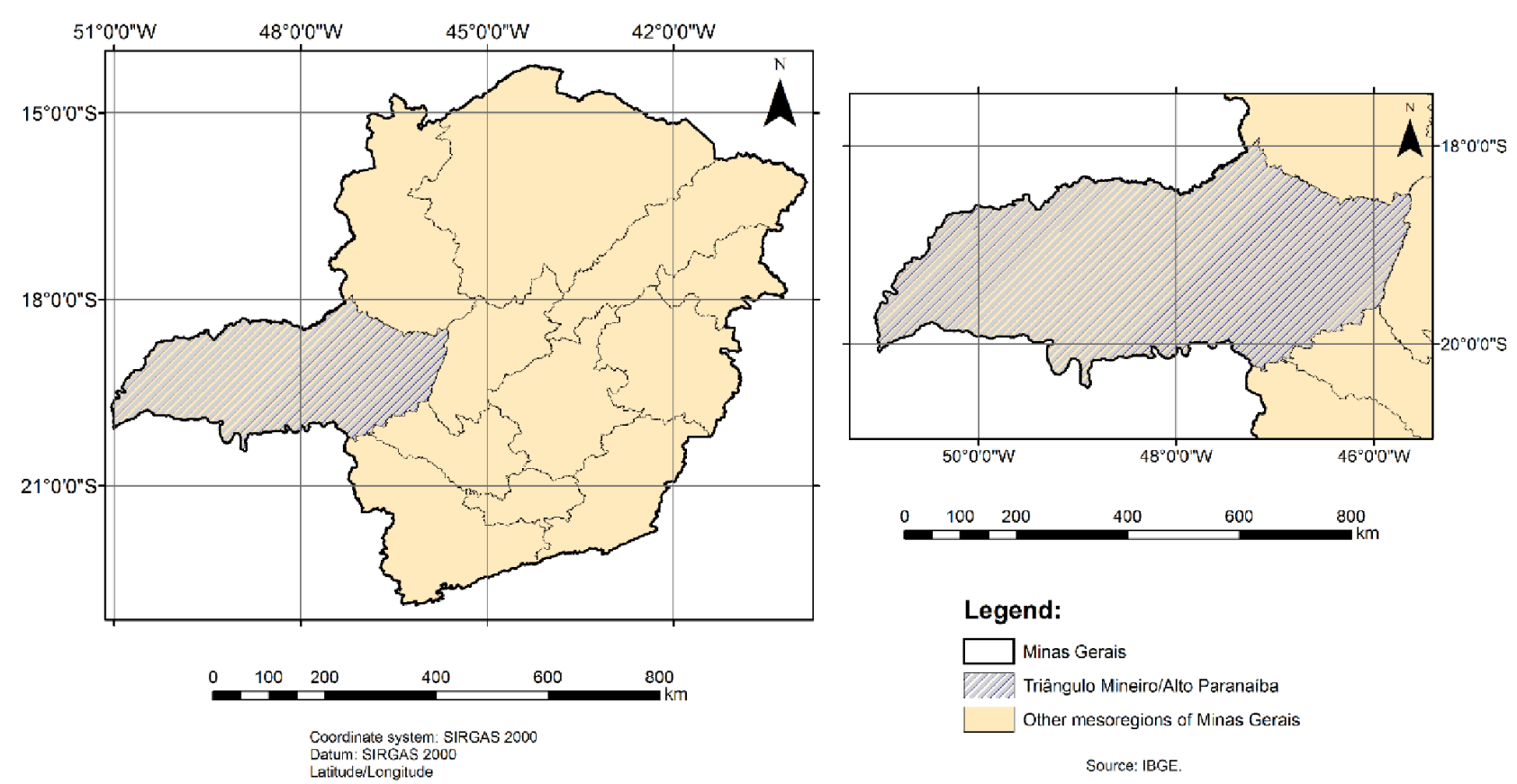

Figure 1: Geographic location of the Triângulo Mineiro/Alto Paranaíba mesoregion in Minas Gerais.

Tropical Rainfall Measuring Mission (TRMM) satellite (NASA, 2016a) was used. The TRMM is a partnership between the National Aeronautics and Space Administration (NASA) and the Japanese Aerospace Exploration Agency (JAXA) and was launched to monitor and study rainfall in tropical areas (Collischonn et al., 2007) and provide estimates more accurate.

The precipitation data were obtained from the time series visualization portal (www.dsr. inpe.br/laf/series/) (Freitas et al., 2011), which provides time series of precipitation estimation obtained from TRMM 3B43 V6 product with a spatial resolution of $0.25^{\circ}$.

Table 1: Coffee planted area on Triângulo Mineiro/Alto Paranaíba in 2009, 2010, 2011 and 2012, obtained from the Systematic Survey of Agricultural Production.

\begin{tabular}{cc}
\hline Year & Coffee planted area $($ ha $)$ \\
\hline 2009 & 151.034 \\
2010 & 155.929 \\
2011 & 152.210 \\
2012 & 154.695 \\
\hline
\end{tabular}

\section{Vegetation index composite products}

The vegetation indices composite products used were MOD13Q1 and VGT-S10. Both are used in agricultural studies because they have spatial and temporal resolutions compatible with the crops size and their temporal dynamics, minimizing problems inherent to the coffee crop areas estimation.

The MOD13Q1 data used in this work were obtained from Land Processes Distributed Active Archive Center - LP DAAC (NASA, 2016). In this work, we used NDVI and EVI from August 2010 to October 2012. The VGT-S10 data are available at (https://free.vgt.be), the international project "GEONETCast for and by developing countries DevCoCast" (Maathuis et al., 2011) database. In this work, we used NDVI from August 2009 to October 2011, and NDWI from August 2010 to August 2012.

Regarding vegetation indices, NDVI, formulated by Rouse et al. (1973), is obtained on the basis of the ratio between the subtraction and sum of near-infrared and red bands reflectance of the electromagnetic spectrum (Equation 1):

$$
N D V I=\frac{\rho N I R-\rho R}{\rho N I R+\rho R}
$$

where $\rho$ NIR and $\rho R$ represent reflectance at the near-infrared and red, respectively.

Huete et al. (2002) point out that its rapid saturation makes it insensitive to the plant 
biomass increase, based on a certain stage of development, a factor that makes it important to use other indices together.

The EVI (Justice et al. 1998) was developed to optimize the vegetation signal and minimize NDVI limitations related to image saturation, mainly observed in densely vegetated areas, caused by atmospheric effects, substrate and acquisition geometry (Huete et al., 2002). The EVI uses red, near-infrared and blue bands of the electromagnetic spectrum (Equation 2):

$$
E V I=G \frac{\rho N I R-\rho R}{\rho N I R+(C 1 x \rho R-C 2 x \rho B+L)}
$$

where $\mathrm{L}$ is a soil adjustment factor, and $\mathrm{C} 1$ and $\mathrm{C} 2$ are coefficients used to correct aerosol scattering in the red band by the use of the blue band. The $\rho R, \rho B$, and $\rho$ NIR represent reflectance at the blue, red and Near-Infrared (NIR) wavelengths, respectively. In general, $\mathrm{G}=2.5, \mathrm{C} 1=6.0, \mathrm{C} 2=7.5$, and $\mathrm{L}=1$.

By minimizing substrate variations and maintaining sensitivity in dense vegetation cover EVI is able to reveal characteristics and phenological variations not revealed in NDVI Simões et al. (2009).

As the water presence in the canopy is another important parameter to crop discrimination, the NDWI (Gao, 1996), related to water content present in canopy and vegetation water stress, was used (Equation 3):

$N D W I=\frac{\rho N I R-\rho M I R}{\rho N I R+\rho M I R}$

where $\rho$ NIR and $\rho M I R$ represent reflectance at the near-infrared and mid-infrared, respectively.

Because it is formulated by bands that correlate well with water of vegetation canopy, near-infrared and mid-infrared, the NDWI indicates changes in biomass and oscillating values of moisture in the plants (Gao, 1996).

\section{Initial processing and sampling of reference points}

The MOD13Q1 and VGT-S10 images were arranged in chronological order (Table 2).
Table 2: Description of the chronological order of the vegetation indices images.

\begin{tabular}{cccc}
\hline Product & Initial image & Final image & $\begin{array}{c}\text { Total of } \\
\text { images }\end{array}$ \\
\hline MODIS NDVI & $08 / 13 / 2009$ & $10 / 16 / 2012$ & 50 \\
MODIS EVI & $08 / 13 / 2009$ & $10 / 16 / 2012$ & 50 \\
VGT NDVI & $08 / 11 / 2009$ & $10 / 11 / 2011$ & 78 \\
VGT NDWI & $08 / 11 / 2010$ & $08 / 21 / 2012$ & 74 \\
\hline
\end{tabular}

We sampled 10 reference coffee crop points, with attested pixel quality (Figure 2). The reference points were obtained from virtual libraries, such as CAFESAT (https://www. dsr.inpe.br/laf/cafesat/) and the Laboratory of Remote Sensing Applied to Agriculture and Forest (https://www.dsr.inpe.br/laf/) (Freitas, 2011), used as a verifier for presenting satellite images and a tool for instantaneous visualization of the MODIS EVI-2 vegetation index time series, which assisted the coffee crop areas identification.

\section{Thresholds definition}

In this step, the thresholds estimation primarily involved the analysis of each vegetation index temporal profile generated. In this case, the total of 10 profiles of each index were generated. Lately, these 10 profiles were used to generate 1 medium profile of each index, aiming interpret the pattern in the mesoregion.

Based on the connection of these medium profiles, the minimum and maximum vegetative vigor images and the coffee phenological phases, were obtained the minimum and maximum thresholds. The minimum thresholds correspond to the values of each vegetation index in the initial phases of phenological cycles, and the maximum thresholds correspond to the maximum vegetative vigor phases of the coffee.

We emphasized that due the objective of evaluate the quality of the raw data available of each product, no filtering methods were applied in this work. All the steps were realized in ILWIS 3.8 version, using the Geonetcast toolbox.

\section{Validation phase}

The validation phase consists exclusively in comparison between the area estimated results 
obtained by the thresholds and IBGE official data of coffee planted area. The difference was expressed in absolute and percentage terms.

\section{RESULTS AND DISCUSSION}

Figure 3 shows the temporal profiles obtained by the MOD13Q1 EVI and NDVI, VGT-S10 NDVI and NDWI, as well as the average precipitation for the period of analysis.

\section{MODIS results}

ForMatielloetal.(2005),therainfallrequirement for coffee varies during the phenological phases. In the vegetation and fruiting phase, the coffee plant needs water available in the soil. In the harvesting and resting period, the need is low and drought does not impair the management and assists cultural dealings. In the NDVI, the lowest values occurred in months preceded by low precipitation, observed in the phenological phases of induction and maturation of floral buds and rest and senescence of the tertiary and quaternary branches. In 2010, 0.39 in the first observation of September. In 2011, 0.43 on the second observation of the same month, and in 2012, 0.39 on the first observation of October.

On the other hand, high values were observed during the phenological phases of increased water demand by coffee plants, phases I: vegetation and floral bud formation and IV: fruit granulation, especially in January and February. In 2010 and 2011, it was 0.74 in the second observation of January. In 2012, the highest value was recorded in the second observation of February: 0.71, indicating a relation with the precipitations.

In the EVI, low values were observed in the phenological phases I: induction and maturation of floral buds and VI: resting and senescence of the tertiary and quaternary branches, in which there is a low water requirement. In 2010, 0.23 in the first observation of September. In 2011, 0.23 in the second record of September, and in 2012, 0.21 in the second observation of September. On the other hand, high values in the phases of higher water demand: I vegetation and formation of

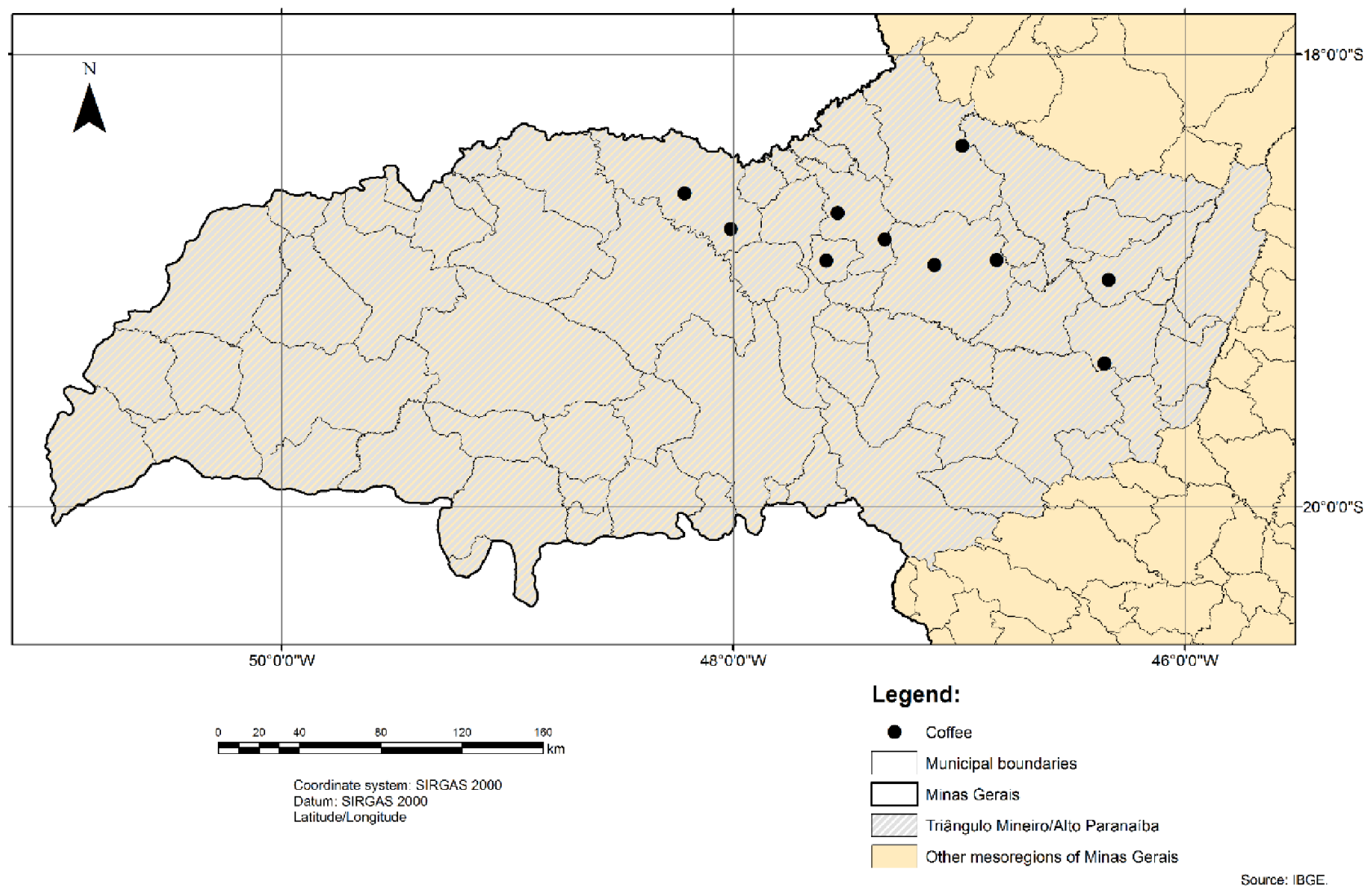

Figure 2: Geographic location of the coffee samples in the Triângulo Mineiro/Alto Paranaíba mesoregion. 

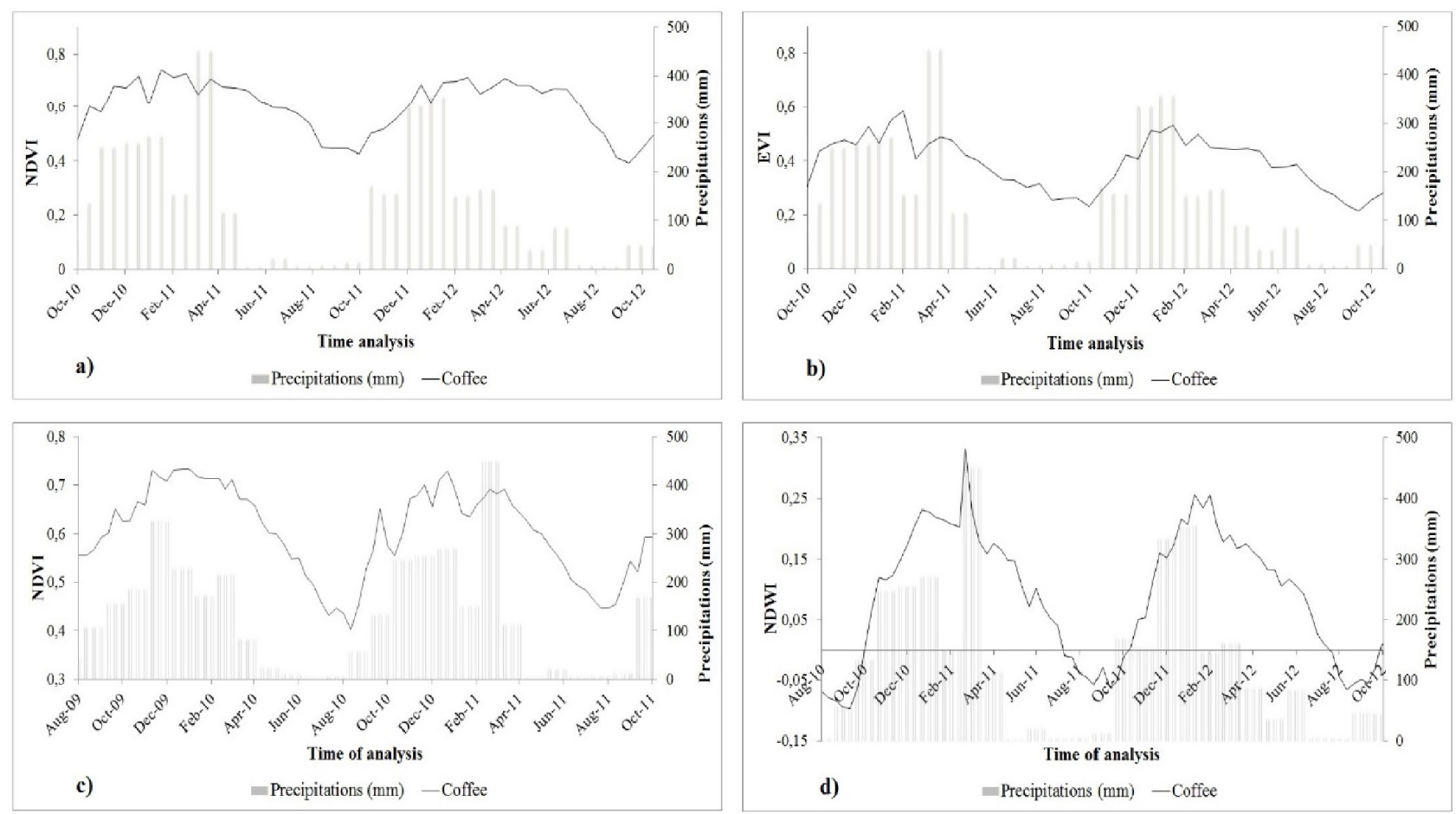

Figure 3: Time series of: a) MOD13Q1 NDVI, b) MOD13Q1 EVI, c) VGT-S10 NDVI and d) VGT-S10 NDWI vegetation products in 10 samples along each specific time of analysis. The MOD13Q1 time series from October 2010 to October 2012, VGT-S10 NDVI from August 2009 to October 2011 and VGT-S10 NDWI from August 2010 to October 2012.

floral buds and IV: fruit granulation, especially in January and February. In 2010, the highest value occurred in the second observation of January, being 0.53. In 2011, the first observation of February (0.58) and in 2012, the second of January (0.53).

\section{SPOT-VEGETATION results}

In NDVI results, the lowest and highest values were recorded in the same MODIS NDVI periods, months of September/October and January/February, respectively. At the end of 2009, the lowest value was recorded in the second observation of October (0.43). In 2010, this value was 0.35 in the second observation of September, and in 2011, on the first observation of September (0.34). One explanation for the lower value of 2009 being higher than 2010 and 2011 is the early onset of rainfall compared to other years detected by TRMM.

With the coffee growth, the NDVI values are increased until the reproductive phase. The highest value recorded in 2009 was 0.78 in the third observation of December. In 2010, it was
0.73 in the third observation of November and, in 2011, 0.76 in the first observation of December. These vegetative peaks are related to the increase of precipitation, since they were reached in times with accumulation of previous rains.

The lowest values occurred in August, in phenological phases II-induction and maturation of floral buds and VI - repose and senescence of tertiary and quaternary branches. The major ones were in January, in phases I - vegetation and floral bud formation and IV - fruit granulation, with higher water demand. The minimum values were 0.55 in the third observation of June 2009, 0.40 in the third observation of August 2010, and 0.45 in the second observation of August of 2011. The highest were 0.74 in the second observation of March 2009; 0.73 in the second observation of January 2010 and 0.73 in the first observation of January 2011.

In the NDWI, high values were recorded between November and March, rainy season and with water demand for vegetation and fruiting. At the end of the harvest, the values fall until they are negative between July and October, harvesting and rest period, where the need for 
water is low and drought is not harmful. The highest values were recorded in January 2011 (0.28), March 2011 (0.33) and January 2012 (0.26), all in the first monthly record. During the negative period, coffee passes through the phenological phases II - induction and maturation of floral buds and VI - resting and senescence of tertiary and quaternary branches, according to Camargo and Camargo (2001), not being affected by the scarcity.

\section{Thresholds definition and coffee crop area estimation}

The coffee crop areas were estimated based on the thresholds established in Table 3.

Table 3: Thresholds in each vegetation index for the coffee crop areas estimation.

\begin{tabular}{|c|c|c|c|c|c|}
\hline \multicolumn{4}{|c|}{ MOD13Q1 } & \multicolumn{2}{|c|}{ VGT-S10 } \\
\hline & NDVI & EVI & & NDVI & NDWI \\
\hline \multicolumn{6}{|c|}{2010} \\
\hline Max & 0.74 & 0.52 & & 0.73 & 0.20 \\
\hline Min & 0.39 & 0.22 & & 0.40 & -0.09 \\
\hline \multicolumn{6}{|c|}{2011} \\
\hline Max & 0.74 & 0.58 & & 0.73 & 0.33 \\
\hline Min & 0.42 & 0.23 & & 0.44 & -0.06 \\
\hline \multicolumn{6}{|c|}{2012} \\
\hline Max & 0.71 & 0.53 & - & - & 0.25 \\
\hline Min & 0.39 & 0.21 & - & - & -0.06 \\
\hline
\end{tabular}

The results of area and the comparison with the IBGE official data (Table 4) demonstrates that the MOD13Q1 have more consonance with the official data.

Initially, it's emphasized that the coffee was chosen due it's considered the more difficulty crop to map. In addition, the choice of Triângulo
Mineiro/Alto Paranaíba for this work was to evaluate the products in the face of such limitation, due to the heterogeneity of land use, with field crops smaller than the size of the image. These conditions were chosen to establish difficulties to test the method.

Regarding the results obtained, the comparison between the evaluated vegetation indices products evidences that the MODIS NDVI obtained minor errors in relation to the IBGE official data, being 3.1\% the largest. In the SPOT-VEGETATION NDVI, abrupt changes occurred: $40 \%, 122 \%$ and $33.6 \%$ in 2009,2010 and 2011, respectively. Its represented advantages of the MODIS NDVI in relation to the SPOTVEGETATION NDVI for estimate coffee crop areas in the Triângulo Mineiro/Alto Paranaíba.

The other vegetation index of MODIS sensor, EVI varies between $12.3 \%$ and $16.7 \%$ along the years. Regarding to the other SPOTVEGETATION index evaluated, NDWI, the highest variation was 77\%, registered in 2012, indicating highly difficulty in the estimation of coffee in this year. In before years, variations of $9.4 \%$ in 2010 and $22.8 \%$ in 2011, also are indicates that the use of this product in high heterogeneous region is not recommended.

Considering these results, it was possible detect that the best vegetation index was MODIS NDVI. Consequently, the thresholds obtained by this vegetation index presents best results. The best minimum threshold varies between 0.39 0.42 and the best maximum varies between 0.71 - 0.74, being considered the best thresholds for the estimation of coffee crop areas in Triângulo Mineiro/Alto Paranaíba. These thresholds corresponding to minimum and maximum vegetative vigor during the harvest period and can be used as parameters for coffee crop masks generation in difference images.

Table 4: Coffee crop area in the IBGE official data and in the results found by the thresholds, and the percentage errors found.

\begin{tabular}{|c|c|c|c|c|c|c|c|c|}
\hline & 2009 (ha) & Error (\%) & 2010 (ha) & Error (\%) & 2011 (ha) & Error (\%) & 2012 (ha) & Error (\%) \\
\hline IBGE & 151.034 & & 155.929 & & 152.210 & & 154.695 & \\
\hline $\begin{array}{c}\text { MODIS } \\
\text { NDVI }\end{array}$ & - & - & 160.781 & $3.1 \%$ & 156.612 & $2.9 \%$ & 157.287 & $1.7 \%$ \\
\hline MODIS EVI & - & - & 182.056 & $16.7 \%$ & 170.987 & $12.3 \%$ & 175.520 & $13.5 \%$ \\
\hline SPOT NDVI & 89.900 & $40 \%$ & 346.600 & $122 \%$ & 101.000 & $33.6 \%$ & - & - \\
\hline SPOT NDWI & - & - & 141.200 & $9.4 \%$ & 117.500 & $22.8 \%$ & 35.600 & $77 \%$ \\
\hline
\end{tabular}


In general, these results indicate that the spatial and temporal resolutions evaluated presents differences. By the spatial magnitude of this analysis, the crop field size may be smaller or higher than pixel size (MODIS pixel is 6.25 ha; SPOT-VEGETATION is $100 \mathrm{ha}$ ).

The difficulty also is explained by the specificity of the coffee crops distribution and detection, in contrast with summer crops. Vicente et al. (2012) demonstrated the SPOTVEGETATION time series potential to estimate sugarcane crop areas in São Paulo, presenting high concordance with official data. Araújo et al. (2011) attested the effectiveness of SPOTVEGETATION 10-day compositions for map summer crops in the State of Paraná. Dubreuil et al. (2012) obtained satisfactory results applying VGT-S10 to monitoring soybean areas in Mato Grosso. In summer crops, the sensor detects the pure canopy, with less soil interference.

In coffee, the plants spacing, and the soil background interference not permits the caption of pure canopy response. In addition, in some cases, the coffee plants are shaded, because the coffee planting in shaded systems is less vulnerable to decrease the LAI in dry season. Shaded systems provide a better climatic condition to coffee crop, protecting the plant from the stress caused by high temperatures and loss of soil moisture (Boulay et al. 2000).

Regarding the area estimation, in the overestimations, neighboring areas may have been added to coffee field crops, and underestimates. Similarly, small areas may not have been detected because of spatial resolutions. As the SPOT-VEGETATION captured area is larger, the response of the pixel is influenced by adjacent areas to the crop, which may explain the higher frequency of super and underestimates.

\section{CONCLUSIONS}

Both orbital products, MOD13Q1 and VGT-S10, presented difficulty to estimate the coffee crop areas in a heterogeneous mesoregion such as Triângulo Mineiro/Alto Paranaíba. However, VGT-S10 presented more differences in relation to the official data. The 10-day frequency of this product captured the seasonality, but the spatial limitation was predominant, causing negative influences in the estimation. MOD13Q1 was also sensitive to the seasonality, but its spatial limitations causing less interferences in the estimates.

About the MODIS vegetation indices, the NDVI presented results more closely to the official data, fact that makes it more suitable to be used as parameter to estimate and identify coffee crop areas in Triângulo Mineiro/Alto Paranaíba. In addition, the best thresholds vary between $0.39-0.42$ (minimum) and between 0.71 - 0.74 (maximum). These thresholds can be used as parameters for coffee crop masks generation.

Due the concordance obtained by this index and thresholds, it's recommended to test the methodology for more extensive coffee crop areas, due to the possibility of pure pixels. In addition, the incorporation of filtering methods can improve the estimations.

\section{ACKNOWLEDGEMENTS}

The authors wish to thank (i) the Federal University of Lavras (UFLA) for providing office space and infrastructure to achieve this article, (ii) the FAPEMIG, process CAGAPQ 01560-12, (iii) the CNPq and CAPES for financial support.

\section{REFERENCES}

ARAÚJO, G. K. D. et al. Mapping of summer crops in the State of Paraná, Brazil, through the 10-day SPOT VEGETATION NDVI composites. Engenharia Agrícola, 31(4):760-770, 2011.

ARVOR, D. et al. Classification of MODIS EVI time series for crop mapping in the state of Mato Grosso, Brazil. International Journal of Remote Sensing, 32(22):7847-7871, 2011.

BOULAY, M.; SOMARRIBA, E.; OLIVIER, A. Calidad de Coffea arabica bajo sombra de Erythrina poeppigiana a diferentes elevaciones en Costa Rica. Agroforestería en las Américas, 7:40-42, 2000.

BROWN, J. C. et al. Classifying multiyear agricultural land use data from Mato Grosso using time-series MODIS vegetation index data. Remote Sensing of Environment, 130(3):39-50, 2013. 
CAMARGO, A. P.; CAMARGO, M. B. P. Definição e esquematização das fases fenológicas do cafeeiro arábica nas condições tropicais do Brasil. Bragantia, 60(1):65-68, 2001.

CHAVES, M. E. D.; MATAVELI, G. A. V.; JUSTINO, R. C. Uso da modelagem estatística para monitoramento da vegetação no Parque Nacional da Serra da Canastra, Minas Gerais. Caderno de Geografia, 24(1):120-132, 2014.

CHAVES, M. E. D. et al. A Geostatistical Approach for Modeling Soybean Crop Area and Yield Based on Census and Remote Sensing Data. Remote Sensing, 10(680):1-29, 2018.

COLLISCHONN, B. et al. Desempenho do satélite TRMM na estimativa de precipitação sobre a bacia do Paraguai superior. Revista Brasileira de Cartografia, 59(1):93-99, 2007.

DUBREUIL, V.; ARVOR, D.; DEBORTOLI, N. Monitoring the pioneer frontier and agricultural intensification in Mato Grosso using SPOT VEGETATION images. Revue Française de Photogrammétrie et de Télédétection, (200):2-11, 2012.

DUVEILLER, G.; DEFOURNY, P. A conceptual framework to define the spatial resolution requirements for agricultural monitoring using remote sensing. Remote Sensing of Environment, 114(11):2637-2650, 2010.

FREITAS, R. M. et al. Virtual laboratory of remote sensing series: visualization of MODIS EVI2 data set over South America. Journal of Computational Interdisciplinary Sciences, 2(1):57-64. 2011.

GALFORD, G. L. et al. Wavelet analysis of MODIS time series to detect expansion and intensification of row-crop agriculture in Brazil. Remote Sensing of Environment, 112:576-587, 2008.

GAO, B. NDWI: a normalized difference water index for remote sensing of vegetation liquid water from space. Remote Sensing of Environment, 266(58):257266, 1996.

HUETE, A. et al. Overview of the radiometric and biophysical performance of the MODIS vegetation indices. Remote Sensing of Environment, 83(1/2):195-213, 2002.
BRAZILIAN INSTITUTE OF GEOGRAPHY AND STATISTICS - IBGE. Unidades da federação. Rio de Janeiro, 2010. Disponível em: (https://www.ibge. gov.br). Access in 10 August 2018a.

BRAZILIAN INSTITUTE OF GEOGRAPHY AND STATISTICS - IBGE. Sistema IBGE de recuperação automática - SIDRA. Disponível em: (https:// www.sidra.ibge.gov.br). Access in 10 August 2018b.

MAATHUIS, B. et al. GEONETCast Toolbox: Installation, configuration and user guide of the GEONETCast Toolbox plug-in for ILWIS 3.7, XML version 1.2. Enschede: ITC, 2011. 151 p.

MAISONGRANDE, P.; DUCHEMIN, B.; DEDIEU, G. VEGETATION/SPOT: an operational mission for the earth monitoring: presentation of new standard products. International Journal of Remote Sensing, 25(1):9-14, 2004.

MATIELLO, J. B. et al. Cultura do café no Brasil: novo manual de recomendações. Edição 2005 - Revisada, ampliada e ilustrada. Varginha: PROCAFÉ, 2005. 436p.

NATIONAL AERONAUTICS AND SPACE ADMINISTRATION-NASA. TROPICAL RAINFALL MEASURING MISSION - TRMM. Disponível em: (https://trmm.gsfc.nasa.gov/). Access in 18 July 2016a.

NATIONAL AERONAUTICS AND SPACE ADMINISTRATION - NASA. Distribute Active Archive System - DAAC. Disponível em: (https:// lpdaac.usgs.gov/). Access in 18 July 2018b.

OLIVEIRA, T. H. et al. Índice de Umidade (NDWI) e análise espaço-temporal do albedo da superfície da bacia hidrográfica do rio Moxotó, PE. Revista Brasileira de Geografia Física, 3(2):55-69, 2010.

ROUSE, J. W. et al. Monitoring vegetation systems in the great plains with ERTS, In: Earth resources technology satellite-1 symposium, 3., Washington, D.C., Proceedings... Washington, D. C.: NASA. Goddard Space Flight Center, 1:309-317, 1973.

SAKAMOTO, T. et al. A two-step filtering approach for detecting maize and soybean phenology with time-series MODIS data. Remote Sensing of Environment, 114(10):2146-2159, 2010. 
- THRESHOLDS DEFINITION IN MOD13Q1 AND VGT-S10 TIME SERIES FOR COFFEE CROP...

SCOLFORO, J. R.; CARVALHO, L. M. T.; OLIVEIRA,

A. D. ZEE - Zoneamento Ecológico Econômico de Minas Gerais. Lavras: UFLA, 2007. 1 CD-ROM.

VICENTE, L. E. et al. Séries temporais de NDVI do sensor SPOT Vegetation e algoritmo SAM aplicados ao mapeamento de cana-de- açúcar. Pesquisa Agropecuária Brasileira, 47(9):1337-1345, 2012. 